\title{
AGGRESSIVENESS AND VIOLENCE IN THE LIFE OF ROMANIAN WOMEN
}

\author{
Agresividad y violencia en la vida de las mujeres de Rumania
}

ANA MARIA DUMITRESCU ${ }^{1}$

\begin{abstract}
Resumen
En Rumania, el periodo bajo el régimen comunista afectó seriamente la imagen de la mujer en la sociedad pero también en la familia, lo que generó varios problemas sociales. Más tarde, la transición desde el socialismo al capitalismo se realizó con dificultad y para enfrentar la situación de crisis (bien social y bien familiar) creada, después del año 1989, los políticos prefirieron «importar» soluciones sin adaptarlas a las necesidades del pueblo, a su estilo de vida pero sobre todo a la religión y cultura de esta nación. Además, la violencia doméstica «siguió su curso normal» todavía considerándose un problema ignorado, protegido en la intimidad de la familia, por la institución del matrimonio y visto como una cosa permitida, aceptada. Los estudios que analizan la situación real de este problema social se realizaron solamente al nivel nacional centrándose más en identificar los casos denunciados, solucionados y los tipos de violencia a las cuales fueron sujetas las víctimas, pero desgraciadamente, hay muy pocos estudios locales o regionales que traten de traer elementos nuevos y específicos. Por lo tanto, este estudio trata de analizar los problemas relacionados a la victimización de la mujer en una zona del Sur de Rumania, concretamente, en la provincia de Argeş, esbozando un retrato de la mujer que vive en esta zona y que presenta un riesgo más alto para abuso e identificando las barreras culturales y estructurales que impiden el abuso y ofrecen la ayuda que necesitan las víctimas para sentirse seguras. Las entrevistas realizadas con las víctimas de la violencia domestica así como el análisis de los expedientes correspondientes, por un periodo de tres años, ponen de manifiesto, aparte de la gravedad de los actos de violencia y de las traumas sufridas, la incapacidad de las autoridades de gestionar este fenómeno que parece extenderse más en los hogares de los rumanos.
\end{abstract}

Palabras clave:: mujer, violencia doméstica, perfil de la víctima, tipos de violencia, Rumanía

\section{Summary}

In Romania, the communist period brought about some serious damage to the image of the woman both at the society and at the family level, a fact that generated numerous social problems. Later on, the transition from socialism to capitalism was carried out with difficulty, and, in order to overcome the crisis situation (both social and familial) created, after 1989 the politicians preferred to "import" solutions without adapting them to the needs of the people, to its lifestyle and especially to the religion and culture of this nation. Moreover, domestic violence "continued its natural course", still being considered a hidden problem, protected by the privacy of the family, by the institution of marriage and conceived as a thing that was allowed, accepted. Studies that should analyse the real status of this social problem were carried out only at national level, with more emphasis being laid on identifying the cases reported and solved and on the types of violence the victims were subjected to, but, unfortunately, the local or regional studies that should bring new and specific elements are very few. For this reason, the present survey tries to analyse the issues related to woman's victimisation within an area lying in the south of Romania, namely in the Argeş County, by shaping a portrait of the woman from this area who presents a high risk of being abused and by identifying the cultural and structural barriers that prevent abuse and provide the means the victims need in order to be safe. The interviews carried out with the victims of domestic violence, as well as the analysis of their files, for a period of three years, render, in addition to the severity of the acts of violence and the trauma suffered, the authorities' incapacity to manage this phenomenon which seems to become more and more present in Romanian households every single day that goes by.

Keywords: women, domestic violence, victim profile, types of violence, Romania.

Recibido: 31/03/2014

Aceptado: 25/09/2014

Publicado: 01/12/2014

1. Pitesti University, Social Work Department, Pitesti, Romania. Str. Targul din Vale, no. 1, Arges. E-mail: amdumitrescu81@yahoo.com 


\section{Introduction}

Partner violence or domestic violence, as it is known in specialised literature, represents an important social problem not only in Romania, but in the entire world. The United Nations defines violence as... "violence that is directed at a woman because she is a woman, or violence that affects women disproportionately. It includes acts that inflict physical, mental or sexual harm or suffering, threats of such acts, coercion and other deprivations of liberty" (UN Secretary General, 2006).

The statistics on this phenomenon are worrying. The European Union takes the view that, at a given moment in the life of a European women, one in five will experience a form of abuse by her partner, whilst $25 \%$ of all abuses reported had to do with assaults by the husband/partner on the wife/partner. At the same time, violence is a major cause of deaths and invalidity for women aged between 16 and 44 years, the number being larger than the number of women deceased from cancer and road accidents (Council of Europe, 2002).

In Romania a woman is hit every thirty seconds and every two days a woman dies as a consequence of the domestic violent acts which she has to suffer (National Agency for Family Protection). The official statistics of the central public authorities show a number of approximately 82,000 reported cases of domestic violence in the period 2004-2011 and 800 deaths (Ministry of Labour, Family and Social Protection (MMFPS).

But, regardless of geographical borders, economic development or level of education, violence represents a major public health issue in all cultures around the world, being aimed in particular at middle-class women (Balci and Ayranci 2005; Krug et al., 2002).

Recent surveys on domestic violence show a high correlation between domestic violence and socio-economic disadvantages, in particular as to regards chronic poverty, social isolation, lack of access to education, employment, development opportunities, mobility and residential population density (Duke and Cunradi, 2011; Hampton et al, 2005; Kasturirangan et al., 2004; West, 1998, 2005). Socio-economic disadvantages are also associated with a range of psychological problems, such as lack of confidence in and respect for one's own person, frustration, shame, all these raising the risk of women's victimisation (West, 2005).

This study is trying to identify certain characteristics of domestic violence by exploring traumatising experiences of women from a region in Southern Romania, the Arges County. The survey was carried out in this area for two main reasons: firstly, it is here that I carry out my professional activity, and the access to information was possible with greater ease, and, secondly, the 
characteristics of the population from this area (a homogeneous area, a limited number of other ethnic groups, a majority being of Orthodox religion, occupations - industry and agriculture) are similar to the characteristics of other counties. Thus, some of the problems identified and the solutions proposed can be generalised at national level as well. It can be stated that among the objectives of this study is the identification of the cultural and structural barriers that prevent abuse by identifying and providing the help women need in order to be safe. This research allows the voices of abused women to be heard in such a way that it could influence the activity undertaken by social services in order to support the victims and take an active part in the assistance and education of aggressors. The issues raised and identified do not refer solely to the victims from this area, but are common to the victims from the majority of regions. From a methodological point of view, the research includes a multicultural perspective with emphasis on culture as the background factor in the justification of abuse and structural barriers within the social system that prevent victims from searching for strategies to help. The research will first analyse the socio-educational characteristics of the victims who benefited from the services of the Emergency Centre of Assessment and Reception for the Victims of Domestic Violence from Campulung, the only centre in the county providing such services, and then will identify the forms of violence the victims were subjected to and then discuss the traumatic experiences they lived. The research methodology includes mixed methods, both quantitative and qualitative, which will explore both perspectives, i.e. of the victims and of the institutions that handle this problem. By using mixed methods it was able to increase the validity and reliability of the data. As a result, research has shown that the nature, extent, dynamics and etiology of violence against women in this region seem to reflect similarities with experiences of abuse from other communities and societies.

\section{Culture - The Background Factor in the Justification of Abuses}

In contemporary Romanian society, the lack of progressive models, the decrease of the standard of living and of education, in addition to the negative social evolution of the Romanian transition led, unfortunately, to the building of men-women relationships within the family based on a patriarchal model. This model was "developed" and labelled as a normal thing, in particular during the communist period, a fact that later (after the fall of the regime) led to many delays but also to failures in the launching of legislative projects and their implementation for the prevention and reduction of the phenomenon of domestic violence. "The communist regime, which, in theory, appreciates 
that women are an important part of the potential of the nation, and in practice led a policy of discrimination and victimisation of the woman, prevented official recognition of this phenomenon, as it was in full contradiction with the <new-type> moral" (Banciu, D., Rădulescu S.M., Teodorescu,V., 2002:40).

Moreover, this regime was marked in the first place by an atmosphere of maximum centralization of the decision-making power, and by the total control of individuals, of society in general, by Ceausescu, who following his megalomaniac policies of massive industrialization of the country, of encouraged the rise in the birth rate at a time when it was decreasing in the rest of the world (in that period, the "woman's body was used in the service of state" (Muntean, A. Munteanu, A. 2011, apud. Kligman, 2000:20) of foreign debt payment and of creation of the new-type, many-sided man, of keeping the individual from having a decent life, thus infringing fundamental human rights.

In 1966 a decree was given by which abortion was forbidden, as well as any attempt of surgical intervention outside the clearly established limits ${ }^{2}$, a measure which aimed at an increase in the labour force. But this measure had a strong impact both on the life of the couple and on family life and even on the sexual behaviour of the individual, as well as on the genetic foundation of the Romanian nation. However, unfortunately, the attempts of abortion by non-medical methods only managed to increase mother and new-born mortality rate, turning Romania into the country with the highest rate in Europe of deaths recorded around birth (Brooke et. al., 2004). Moreover, this measure led to an increase of the number of abandoned children and, implicitly, to the overcrowding of orphanages.

All the measures imposed by this regime, not only those relating to family, but also those targeted at economic growth, foreign debt payment and others did nothing but arouse feelings of "disappointment, hatred and helplessness" (Kogan, 2001:101).

Against the background of these social tensions, the mentalities that also concerned the attitude of the individual toward domestic violence were created, which continued even after the fall of communism. The lack of institutions and laws that should counteract the proliferation of this phenomenon made it possible for domestic violence to not be perceived as a "problem" that required urgent solutions and the suffering that it caused should be completely ignored. As a proof of this indifference, one may invoke the Romanian

2. The right to resort to abortion was granted to: women over the age of 40 , with four dependent children, with severe hereditary contagious diseases, with severe physical, mental or sensory diseases, in whose case pregnancy could endanger their life, as well as in the case of pregnancy resulting from rape or incest. 
proverbs $^{3}$ of the day, which also include discriminatory syntagms, among which we can mention "Femeia nebătută e ca moara neferecată, „Dacă nu ştii de ce îţi baţi nevasta, lasă că ştie ea” ",Femeia şi nucul trebuie batute” ,Femeia nebătută este ca o casă nemăturată”; ,, Moara se bate de 3 ori, iar femeia de 6 ori pe zi", Muierea d-aia-i muiere, să sufere", Femeia trebuie bătută chiar dacă nu a făcut nimic pentru că oricum o să facă" (our translation: "The woman who is not beaten is like the mill which is unbound", "If you don't know why you are beating your wife, don't worry, she knows", "The woman and the nut tree must be beaten", "The woman who is not beaten is like a house which is not swept", "The mill is beaten 3 times and the woman six times a day", "A woman's role is to suffer", The woman must be beaten even if she has done nothing wrong - she will do something wrong anyway"). But no matter how amusing and harmless jokes and giggles may seem at first, they also fulfil the role of marking and reminding the inferior position the woman occupies in society.

In this context, women's abuse constitutes an extension of "normal" and accepted behaviour and not deviant behaviour. Virtually all men may use violence to subject and subordinate women if they choose to do so (Curic I., Văetişi L., 2005, apud. M. Davies, 1994).

The issue of domestic violence in Romania came to the attention of specialists only around the 1990s, when with support from UNICEF, governmental structures with a view to preventing violence in the family were set up, but these often changed their name, which demonstrated the difficulty of integrating them in the institutional framework. Starting with that period, there have been attempts of drawing statistics to identify the scale and the defining elements of this phenomenon. But the studies were carried out at national level, laying more emphasis on the number of cases identified and on a number of aspects related to the types of violence experienced by the victims. For this reason, the carrying out of a study at a local level may bring separate and at the same time important elements to complete the "picture" of women's victimisation in Romania.

\section{Material and methods}

The principal objectives of this study are the analysis of the structure of a group of women, victims of domestic violence, in order to identify certain individual and collective characteristics, to highlight the typology of the victim of domestic violence and the description of the forms of violence they were

3. The proverbs focus on truths for different communities, confirming the social values and rules and also contributing to the perpetuation of certain stereotypes. 
subjected to by the partner in order to identify the cultural and structural barriers that prevent the abuse by identifying and providing the help the victims need in order to be safe. These objectives represent only a part of the sociological endeavour, since the phenomenon of domestic violence is complex and at the same time sensitive and is influenced by the context and the individual variables, difficult to capture in structured research.

The analysis of the matter was carried out on the basis of qualitative and quantitative research, using observation as a method before the launching of other instruments, and of the technique of direct investigation, of the faceto-face type. As a method, an intensive-type method was used, namely the interview that was composed of questions which were mainly targeted at information with regard to the forms of violence which the victims were subjected to, as well as to the relevant aspects of their lives. The methodology for these individual interviews was based on a theoretical approach (Allen, 2011; Charmaz, 2000, 2003) by allowing women's voices to be heard and listened to without attracting the researcher's prejudices.

This type of non-directive interview allowed for the gathering of a large number of data over a relatively short period of time by offering a higher degree of freedom to the complete exploration of the phenomenon and concomitantly providing the victims with freedom of expression during the interview. The study involved a ten victims who were present at that moment in the shelter, while the procedure of selection of participants was a theoretical sampling. The ethical approval for this study was granted by the General Department of Social Assistance and Child Protection, Arges, and each of the women involved were informed of the confidentiality of the information supplied on their names and residence. All respondents gave their consent in writing, being also informed of the right to refuse and/or withdraw their data, at any time, or to refuse to answer certain questions or discuss the topics raised. However, all respondents wanted to answer the questions and to discuss issues related to their life. Interviews had an indeterminate duration, offering participants more flexibility in the expression of opinions. At the same time, during the interview many efforts were made for the victims interviewed to feel at ease, which made it possible for them to answer the sensitive questions. The victims that were interviewed are aged between 18 and 31 years, come from the rural area and do not have a job.

The creation of working instruments was based on the operationalisation of the main concepts. The analysis of the data and the processing of the responses obtained through the interview and the observation sheet were carried out by means of content analysis, the relevant aspects were collected 
and summarised and the relevant fragments of discussions were quoted in the study.

At the same time, the study intended to carry out a casuistic analysis based on the collection and interpretation of the data on violence against women using working documents from the files of abuse cases investigated by the specialists with the General Department of Social Assistance and Child Protection, Argeş County during 2009-2011. An analysis of these documents was aimed at identifying certain aspects related to the socio-family status, the causes and forms of aggression, involvement of authorities in the handling of previous aggressions, involvement of minor children in acts of violence, as well as the solutions identified by the authorities in order to solve the problems.

These strategies of research were used to access as many views and experiences as possible.

\section{Limits}

An important limitation of this study is related to the selection of the interviewees. As the selected women in domestic violence situations were those that benefit from social services, it was not possible to render the situation and the perspective of the women who did not apply for institutional support. At the same time, a large part of the results obtained after this study cannot be generalised at the national level, because the sample is not representative, but nevertheless it allows the delineation of certain aspects related to the occurrence and the severity of this phenomenon not only in the Argeş County, but also in Romania.

\section{Results}

The cultural context of the Argeş County highlighted in this study can be described as a united community, which supports traditional family, the values and the insolubility of the marital relationship. Women's roles in this community are centred in the first place on the child and oriented towards the family but also towards their place of employment. But women who are faced with instances of aggression from their partner have limited financial resources (the vast majority of them being financially dependent), live in the extended family of their partner/husband, and religion and traditional family values "lock" them in this abusive situation. This pressure to remain married, whatever the costs, is exerted on both sides. These intra-cultural pressures interact with the structural difficulties that exist within the social institutions 
that provide help to the abused women when they are in situations of abuse and ask for help.

The study carried out in the county in 2012 (Dumitrescu A. M., PhD thesis, not published yet) analysed cases of certain women on the record of the Emergency Centre of Assessment and Reception for the Victims of Domestic Violence from Campulung, Argeş County ${ }^{4}$, between 2009-2011. Although they do not constitute a representative sample at the national level (since the presence of victims has a random character, and their number is rather low), the victims contained in this study constitute an "off cut" of the women's victimisation in the Argeş County and gives an overview on the categories of women who have a high risk of vulnerability in the country.

With a view to identifying the defining elements of this social phenomenon (recognized, assumed and declared), the persons' files were analysed (documents: disposition of granting of services, the initial assessment sheet of the case) that benefited from the specialised services of the Centre and interviews were carried out with a group of victims.

After analysing the files, several characteristics of the persons benefiting from specialised services were identified, thus enabling the design a profile of the domestic violence victim in this region, and also identifying the cultural and structural barriers.

Half of domestic violence victims who appealed to the services of the Centre were aged between 31 to 40 , being followed by victims aged 18-30, with a weight of $39.4 \%$ The low-vulnerability women's groups are those younger than 18 years $(3.0 \%)$ and those over 51 years. The high degree of vulnerability at the age of maturity can be explained from several points of view: most of them have minors as dependents who need the financial support of their father, they are more emotionally dependent on their partners, it is the most sexually active age group.

The rural environment is the origin of the majority of victims $-63.7 \%$ (because so many young girls begin their relationship of marriage/concubinage earlier, the education level is low, the financial dependence on the partner is very frequent, the traditional and religious rules on the social

4. The Emergency Centre of Assessment and Reception for the Victims of Domestic Violence from Campulung, Argeş County is the only centre that provides such services in the county. This situation is encountered in almost all counties in Romania, thus there are 59 shelters for the victims of domestic violence, of which 38 are public, 2 - in publicprivate partnership and 19 - private; and 20 centres for the prevention and combating of domestic violence, of which 10 are public, 1 - in public-private partnership and 9 - private. Unfortunately, there still exist a few counties where there is no centre for the victims of domestic violence. 
and family roles of gender are more powerful), but the percentage differences between the two residential environments are not significantly different statistically.

With regard to the level of education, 54.6\% completed secondary-school studies, $18.1 \%$ classes I to IV, $15.1 \%$ followed vocational school training, and 12.2 percent attended high-school courses. The percentage of employment is very small, only $15.2 \%$; the activities they engage in are those of seller, tailor, waiter, etc. The large majority of the victims are home-makers, they have never worked either because their partners did not allow them to get a job or because they gave up work to take care of the children and household (therefore they had a precarious financial situation, making a low income ranging between 45 and 130 EUR per month). According to these results, the low educational level involves a lower level of economic development, which makes the level of violence increase. Specialised literature also confirms this, that most women who are experiencing violence have a low level of education (Erci 1997; Constantinescu, M., 2008; Lawoko 2006; Olavarrieta et al. 2002; Rickert et al. 2002; Stephenson et al. 2006) as well as a low economic status (Black et al. 1999; Kishor and Johnson 2006).

At the same time, statistically the rate of domestic violence differs significantly based on the status of the person being surveyed as well as of the family type (with or without minors). Thus, most cases of domestic violence took place in the relations of concubinage because of the instability of this type of cohabitation that does not offer couple cohesion and safety. Within the legally married couples, the rates of domestic violence are to be found around the average values of violence recorded at national level.

As is clear from the statements of the victims who left their houses and appealed to the services of the Centre, $97 \%$ had minors as dependents and in most cases the latter accompanied the victims (their mothers) to the Centre (either because they were abused or for fear of being blamed for their mother's leaving, or because of the emotional dependence on the mother), also benefitting from specialised services.

The analysis of the interviews conducted at the Centre highlighted in particular aspects linked to the inner feelings of the victims from the period of the abuse. They didn't have confidence in their own strength and in what they were doing, they were timorous and very suspicious of the intentions of those around them, they had suicidal thoughts, feeling abandoned. 
Chart 1. The socio-educational characteristics of the victims who benefited from the services of the Centre for victims of family violence

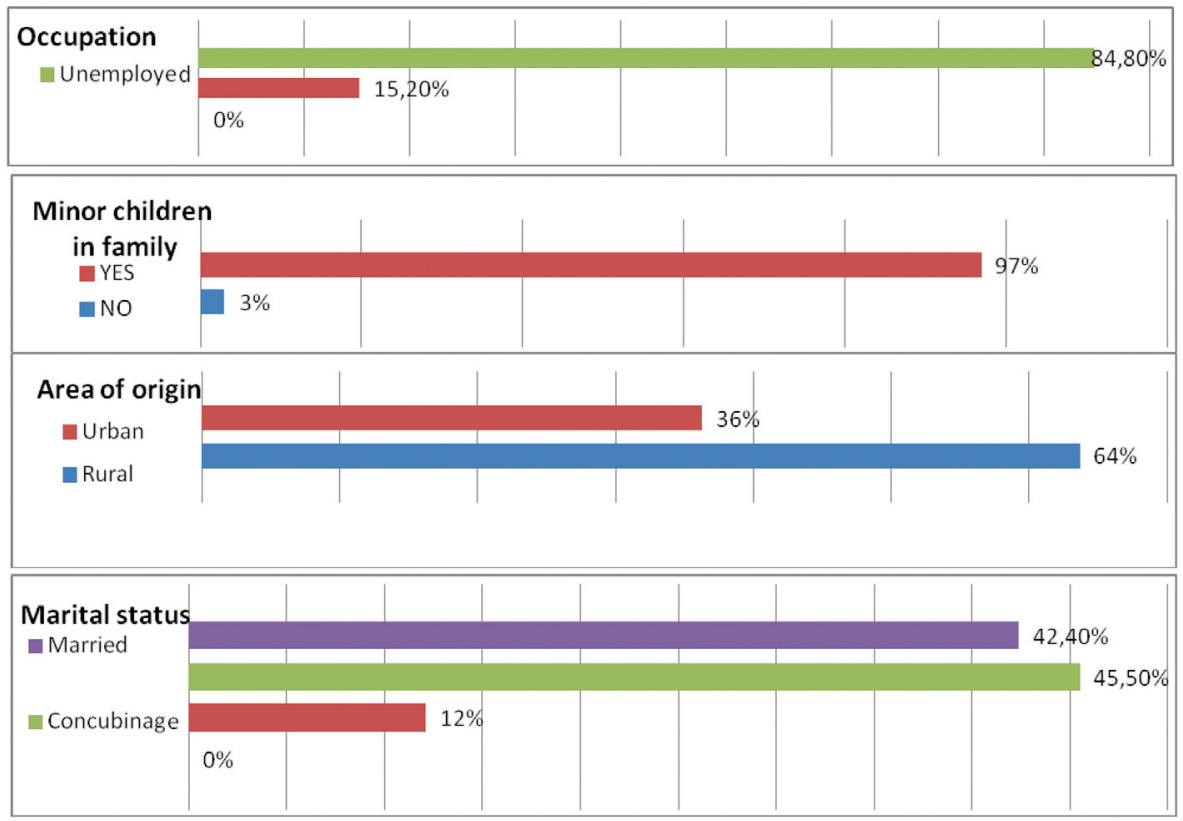

Source: own elaboration

"I took pills on many occasions ... the last time I was found and taken to the hospital by my mother-in-law".

(Female victim, 36 years old)

"I'm not sure if I really want to die, I want this suffering to stop ... I just want it to end, I can't see any other way out...

(Female victim, 31 years old)

"I had nightmares, I couldn't eat... I had one problem, then I had another, I felt lost, nobody asked me about my marriage, about my childhood, whether it was happy or not ... I felt that everyone hated me".

(Female victim, 29 years old)

Fortunately, the shelter gave them the chance to socialise with other victims, to share experiences and feelings related to the turbulent life which they had led and, furthermore, they benefited from specialised social, medical, legal and psychological services. In their turn, the children also benefited from the services of the Centre, and moreover were enrolled in schools in the city in order to continue their studies. 
Within the same study an attempt was made to highlight the main forms of aggression the victims were subjected to. After conducting the interviews, it was found that there are no "pure" types of abuse, but rather correlated forms, therefore an act of physical violence was preceded by several acts of emotional and verbal abuse.

Chart 2. The forms of violence the victims who requested the services of the Centres for victims of family violence were subjected to.

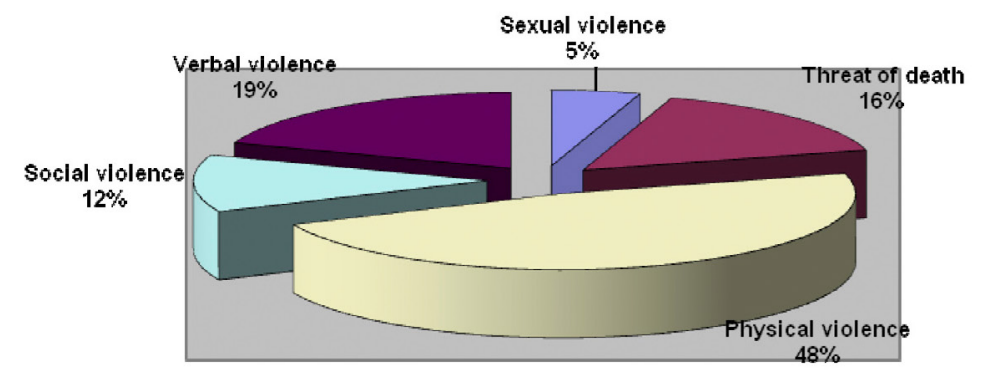

口Sexual violence $\square$ Threat of death aPhysical violence asocial violence aVerbal violence

Source: own elaboration

Thus, it was determined that physical and psychological violence have a high share both in urban and rural areas, whilst social violence is more frequent in urban areas. At the same time, in $47.2 \%$ of the cases of aggression against the woman, the children of the victims were also present.

During the interviews the victims mostly acknowledged physical violence, which most often took rough forms, affecting their physical integrity.

In this respect, from the interviews that were carried out the following can be mentioned for edifying purposes:

"He would even send me carolling to make money, at that time people would believe me because I was young, but now... and one evening I came home at two o'clock at night and I brought him 1,200 lei, he took it and then left and I tried to get some sleep because I was tired and frozen. In the morning, I woke up being hit with his fists and feet in the face without any reason.... one day he even hit me with a crowbar, but I could never bring myself to leave him because he was like a god to me".

(Female victim, 21 years old) 
"He was very jealous, he always kept me in and if I ever went to the store without him, when I came back he would beat the living tar out of me ... he would hit me with whatever he found in the house.... and would always say that he would kill me".

(Female victim, 29 years old)

"He beat me every day, many times with no reason, he hit me with his fists and feet especially in the head... I even lost a twin pregnancy because of him and when I got pregnant again he beat me as hard, he only hit me in the head... and after I gave birth he didn't care at all, he continued to beat me, he said that the child was not his".

(Female victim, 18 years old)

The forms of physical violence are varied, often combined, beating being considered the most complex and comprehensive of all. As results from the descriptions made by the victims, the most common ways of expressing the aggressor's negative emotions and anger are: shoving, arm twisting, throwing objects at the victim, hair pulling, hitting with the hands or feet, hitting with various contusive objects (belt, bat, etc.), thrusting the victim against the walls or furniture, depriving the victims of sleep and/or food, etc.

In almost all the cases under study, the direct and indirect threat is the form of emotional violence with the highest frequency reached at by various means: words, gestures, facts, etc. The distortion of reality by the aggressor is another form of violence, by which the latter seeks to change the ideas and beliefs of the victim as he wishes. Denigration, public insults, frequent accusations of infidelity (without reason), lying, defying are often used by an aggressor to intimidate the victim. Intimidation can be carried to the extremes, causing the gradual installation of fear that will hardly allow itself to be removed, requiring specialised intervention. Deprivation of liberty or of the goods necessary for subsistence, the frequent repetition of the fact that the victim is no good or that she is useless are other forms of violence frequently invoked by the victims.

Verbal violence manifested itself under various forms, the most frequent instances being offences, insults in public, high tone and conflicts in the presence of children.

Sexual violence expressed itself through an inappropriate behaviour of the aggressor towards his partner, especially in the presence of children, who, due to a lack of space and care of the adults, are witnesses to the indecent behaviour of their parents. Marital rape was reported in $20 \%$ of the cases, and offences with sexual connotations are commonly found in most of the situations analysed. 
Social isolation as a form of violence was identified among almost a quarter of the cases and was exercised by the aggressor to maintain control in the couple relation and to remove any form of communication of the victim with the outside. This way, it was impossible for the victim to resort to the neighbours' help or to relatives or to denounce acts of violence.

Regarding the victims' reactions, they are diverse, from a total lack of reaction up to responding with acts of violence in their turn. The answer chosen by the woman "depends on the one hand on the support she is receiving or knows that she can ask from the close ones, and on the other side on the form of violence experienced" (Radulescu 2008: 110-111).

More than half of the women abused declared that they were afraid to react, only trying to calm down the aggressor; a quarter replied with verbal violence in their turn and almost a quarter of the victims tried to defend themselves in a variety of ways: they ran, they answered the challenges, used threats etc. The children's attitude is to be noted. According to the information contained in the files and interviews, in about $90 \%$ of the cases, the children agreed and even encouraged their mothers to leave the aggressive husbands, accompanying them to the Emergency Centre of Assessment and Reception for the Victims of Domestic Violence from Campulung.

"he beat me every day...there was nothing I could do, I had to abide, his mother always said he was right and was glad when he started to beat me... he beat me even when I held the child in my arms...but I stayed there, I had nowhere else to go..."

(Female victim, 18 years old)

"He was very violent... but where to go, what to do! The children asked me to leave him many times, but I was afraid he would find us and it would be a lot worse. He was violent both with me and with his parents! There were cases when Andrei asked for the neighbours' help to save his grandpa".

(Female victim, 29 years old)

"If he hit me I hit him too, but sometimes only I hit him to make him understand I was not afraid of him".

(Female victim, 36 years old)

"The last time, he hurt me rather bad and I wanted to defend myself... and I found a knife and I hit him ....I hurt his hand pretty bad..."

(Female victim, 30 years old)

"He hit me in front of the children, he had no shame and if they told him to leave me alone he said I taught them to say that...but the poor children only wanted to protect me from that crazy man."

(Female victim, 33 years old) 
All the victims who came beaten (bruises, fractures, infections of open wounds, etc.) to this Centre were advised to obtain a forensic medical report to initiate legal proceedings against their abusive husbands. The situations that were very serious were transferred to the Campulung Municipal Hospital, but the police forces were also informed, regardless of the victim's option.

Unfortunately, a number of barriers that prevent the victims not to require specialised help were identified. Firstly, the law tends to protect children in situations of violence rather than women, thus they are afraid to lose them, and the cultural barriers (the patriarchal culture of the community, religion, insolubility of marriage, the role of women to raise and take care of children, the protection of the family name) are sometimes decisive, thus the victims prefer to remain in the abusive relationship for a long period of time, sometimes even for all their lives.

In addition to these "internal" community barriers there are "external" barriers at the level of the community. About 36\% of victims who benefited from the services of the Centre stated that, before being admitted, they appealed to a specialised service, in particular to the police, once or several times, but the authorities did not respond to the requests of victims in all cases out of a desire not to add cases involving the same author (the aggressor was being investigated for other crimes as well). Other reasons for which victims did not require specialised help would be the fact that they did not know about the existence of such services, or do not have a financial situation which would enable them to pay the taxes levied by some of the services.

But for the victims who requested specialised help, the major problem appears at the end of the period of residence in the Centre, when most have to return to the environment which they left before, and although they benefited from social and psychological counselling, the fact that the aggressor was not included in a program of rehabilitation increases the risk for the victim to be assaulted again. As a consequence, about $40 \%$ of the female beneficiaries returned to the Centre after a short period of time to ask again for support and help.

From these considerations, it is clear that it is necessary to set up centres for the aggressors as well ${ }^{5}$, otherwise the intervention in cases of domestic violence will be superficial, short, and with a high degree of relapse.

Because of the poor awareness of the destructive effects that domestic violence has on the person, or because of the lack of identification of domestic

5. In Romania, although this is stipulated in the law, at present there are only 3 centres providing social services targeted at family aggressors. 
violence as a social problem at the level of mutual consciousness, violent behaviour is maintained and sometimes even strengthened. Members of the family give the impression that violence appears to be a private problem that should be settled inside the couple and not outside it. This is due to the lack of confidence in the capabilities of the formal system to intervene effectively or because of certain social prejudices which place the blame on the victim as well (National Agency for Family Protection, 2009). All these lead to the development and the maintenance of a tolerant behaviour towards domestic violence.

\section{Conclusions}

The forms of violence discovered after the analysis of files, as well as those reported by the women interviewed, reflect the forms of violence identified in most studies on domestic violence, and that is physical, verbal, psychological and social abuse. The nature, the extent, the dynamics and the etiology of violence such as reported by respondents in this study seem to reflect very carefully experiences of abuse of other communities and societies as well (GarciaMoreno et al., 2006). At the same time, the portrait of the victim drawn in this study shows that economic disadvantages and the low level of education increase the risk of victimisation, in particular with regard to women in rural areas. However, violence does not only have to do with statistics, it is a real fact that is happening in a society that is still concentrated on men's aggression against women.

Intervention in situations of domestic violence is done with great difficulty because there is a single shelter which must cover the entire county, the police still intervenes with difficulty because of cultural and religious barriers (domestic violence is still considered a private problem), and the community, due to the existing patriarchal culture, does not consider violence against women as a serious problem. This is why it is necessary both to make the community aware of the issue and to train specialists with a view to identifying the barriers that are specific to the safety of women both within the respective community and in society in general.

Although after conducting the survey at local level numerous "common elements" with studies carried out at national level were found, as claimed by Burton (2008), intervention must be carried out individually and in a differentiated manner by taking into account the characteristics specific to the region, lifestyle, religion, level of education or occupation, role expectations, social opportunities and social restrictions. Thus, the social workers' knowledge of the cultural context becomes a necessity, because the improvement 
of the practical skills will provide more help to the women in situations of abuse.

Female victims of domestic violence need more psychological assistance, primary legal assistance related to the divorce procedure, division of property, the right over children, because, as is clear from this study, the vast majority of the victims have a low level of education, therefore they do not know their rights as citizens and as life partners, and in particular do not know what to do in such situations. Furthermore, the lack of legislation to protect victims makes it almost impossible for them to have access to specialised services; therefore they prefer to keep silent, to accept and to lead a life marked by aggressiveness and violence.

At the same time, the services for victims of domestic violence in this area and in Romania are few in number and very poorly promoted, this being the reason why they are known by a very small number of potential beneficiaries. The current services provide only crisis intervention, but the victim's needs are much larger and require more time (not just 60 days) to be satisfied, and the long-term assistance services are totally absent.

Unfortunately, the problem of Romanian women continues to be kept at the periphery of the politicisation of their political interests, therefore at the periphery of public and budgetary policies.

\section{Bibliography}

Agenţia naţională Pentru Protecţia Familiei. (2009). Ghid de intervenţie în cazurile de violenţă în familie. Bucuresti.

Agenţia Naţională pentru Protecţia Familiei, [Online] Available on: http://www. anpf.ro/statistica/ (12 June 2010).

Allen, M. (2011). Violence and voice: Using feminist constructivist grounded theory to explore women's resistance to abuse. Qualitative Research, 11, 23-45.

BALCI, Y. G., AYRANCI, Ü. (2005). Physical violence against women: Evaluation of women assaulted by spouses. Journal of Clinical Forensic Medicine, 12, 258-263.

BANCIU, D., Rădulescu, S.M., TEOdoresCu,V. (2002). Tendinţe actuale ale crimei şi criminalităţii din România. Bucureşti: Lumina Lex.

Black, D. A., Schumacher, J. A., Smith, S. A. M., Heymen, R. E. (1999). Risk factors for partner abuse and child maltreatment, a review of literature. National Network of Family Resilience. Available from http://www.nnh.org/risk/.

Broke, R., JOHnSON Horga, M., Fajans, P. (2004). A strategic Assessment of Abortion and Contraception in Romanian. Reproductive Health Matters, 12(24), 184-194. 
Burton, M. (2008). Legal Responses to Domestic Violence. London - New York: Routledge.

Charmaz, K. (2000). Constructivist and objectivist grounded theory. N. R. Denzin, Y. S. Lincoln (eds), Strategies of Qualitative Inquiry, Thousand Oaks, CA, Sage, 509-35.

Charmaz, K. (2003). Grounded theory: Objectivist and constructivist methods. N. R. Denzin, Y. S Lincoln. (eds), Strategies of Qualitative Inquiry, Thousand Oaks, CA, Sage, 249-91.

CONSTANTINESCU, M. (2008). Familia între tradiţie şi modernitate. Piteşti: Editura Universităţii din Piteşti.

COUNCIL OF EUROPE. (2002). Domestic violence against women: Stop violence against women, Recommendation 1582.

CURIC, I., VĂETIŞI, L. (2005). Inegalitatea de gen: violenţa invizibilă: ghid de lucru pentru conştientizarea şi eliminarea violenţei împotriva femeilor. Cluj-Napoca: Eikon.

DukE, M. R., CunRADI, C. B. (2011). Measuring intimate partner violence among male and female farmworkers in San Diego County, CA. Cultural Diversity and Ethnic Minority Psychology, 17(1), 59-67.

Dumitrescu, A. M. (2012). The Impact of Domestic Violence on Women's Social and Family Life in Romania, the Argeş County. Unpublished doctoral thesis. University of Bucharest, Romania.

ERCI, B. (1997). Married women's rates who are exposed to violence and impact on women's health. Sendrom, 9(8), 86-89.

Garcia-Moreno, C., Jansen, H. A. F. M., Ellsberg, M., Heise, L. Watts, C. (2006). Prevalence of intimate partner violence: Finding from WHO multicountry study on women's health and domestic violence. Lancet, 368, 1260-9.

Hampton, R. L., Carrillo, R., Kim, J. (2005). Domestic violence in African American communities. N. J. Sokoloff, C. Pratt (eds), Domestic Violence at the Margins: Readings on Race, Class, Gender and Culture, New Brunswick: Rutgers University Press, 127-41.

Kasturirangan, A., Krishnan, S. AND Riger, S. (2004). The impact of culture and minority status on women's experience of domestic violence. Trauma, Violence, and Abuse, 5(4), 318-32.

KISHOR, S., JOHNSON, K. (2006). Reproductive health and domestic violence: Are the poorest women uniquely disadvantaged? Demography; Health $\&$ Medical Complete, 43(2), 293-307.

KogAN, I. (2001). Romania and its Unresolved Mourning: Those who emigrated and those who stayed behind. Mind and Human Interaction, 12(2), 95-106.

Krug, E. G., Mercy, J. A., DAhlberg, L. L., Zwi, A. B. (2002). The world report on violence and health. Lancet, 360(9339), 1083-1088. 
LAWOKO, S. (2006). Factors associated with attitudes toward intimate partner violence: A study of women in Zambia. Violence and Victims, 21(5), 645-656.

Ministerul Muncii, Familiei şi Protecţiei Sociale. [Online] Available on: http://sas. mmssf.ro. (02 February 2012) and Available online at: http://www.mmuncii. ro/ro/minister/organizare-48-view.html, (01 June 2012).

Muntean, A. Munteanu, A. (2011). Violenţă, Traumă, Rezilienţă. Iaşi: Polirom.

Olavarrieta, C. D., Ellertson, C., PazA, F., LeOn, S. P., Segovia, D. A. (2002). Prevalence of battering among 1780 outpatients at an internal medicine institution in Mexico. Social Science E Medicine, 55, 1589-1602.

RăDUlEsCU, A. (2008). Violența asupra femeii. București: Editura Universității din București.

Rickert, V. I., Wiemann, C. M., Harrykissoon, S. D., Berenson, A. B., Kolb, E. (2002). The relationship among demographics, reproductive characteristics, and intimate partner violence. American Journal of Obstetrics and Gynecology, $187,1002-1007$.

Secretary-General of United Nations. (2006). Study on violence against women. General Recommendation No. 19, [Online] Available on: www.un.org/womenwatch/daw/vaw/SGstudyvaw.htm (11 december 2010).

Stephenson, R., Koenig,M. A., Ahmed, S. (2006). Domestic violence and symptoms of gynecologic morbidity among women in North India. International Family Planning Perspectives, 32(4), 201-208.

WEST, C. M. (1998). Lifting the "political gag order": Breaking the silence around partner violence in ethnic minority families. J. L. Jasinski and L. M. Williams (eds), Partner Violence: A Comprehensive Review of 20 Years of Research, Thousand Oaks, SAGE Publications, 184-209.

WEST, C. M. (2005). Domestic violence in ethnically and racially diverse families: The "political gag order" has been lifted. N. J. Sokoloff and C. Pratt (eds), Domestic Violence at the Margins: Readings on Race, Class, Gender and Culture, New Brunswick. Rutgers University Press, 157-73, [Online] Available on: www.courtsservice.ie (11 February 2010).

\section{DISSEMINATION HISTORY}

Presented in part as a speech to the Joint World Conference on Social Work and Social Development: Action and Impact, Stockholm, Sweden 8-12 July 2012 